\title{
PEMANFAATAN GOOGLE TRANSLATOR SEBAGAI MEDIA PEMBELAJARAN PADA TERJEMAHAN TEKS BERITA ASING
}

\section{Utilization Of Google Translation As A Learning Medium At Foreign News Text Translation}

\author{
Muhammad Shalehuddin Al-Ayubi
}

\author{
Pustekkom Kemendikbud \\ JI. RE. Martadinata, Km. 15,5 Ciputat Tangerang Selatan, Banten, Indonesia \\ m.shalehuddin@kemdikbud.go.id
}

\begin{abstract}
Diterima: ABSTRACT: Google Translator is a medium that can facilitate 10 April 2017, direvisi: learners to translate text of various languages into a certain language, including text of English into Bahasa Indonesia. However, learners 28 April 2017, disetujui: 5 Mei 2017. often find errors and irregularities in the translated text. The purpose of this study is to analyze the effectiveness of Google Translator used as a medium of language learning, viewed from the translation results. In translation, there are two forms of equivalences, namely formal equivalence and dynamic equivalence. This research is a qualitative descriptive case study. The analized data is translated foreign news text in online media. Data sampling is done through random technique. The result shows that the formal equivalence is almost achieved by Google Translator. However, based on acceptability parameter, it can be concluded that the translation results with Google Translator is not in good category. Meanwhile, translation result by kompas.com journalist as the comparison shows that eventhough it doesn't reach formal equivalence, it is in good category of acceptability. Based on the analysis, Google Translator is considered effective as a language instructional medium eventhough it is not in good level of acceptability.
\end{abstract}

Keywords: Google Translation, language learning media, translation acceptability, news text translation

ABSTRAK: Google Translator merupakan salah satu media yang dapat memudahkan pembelajar untuk menerjemahkan teks dari berbagai bahasa ke dalam bahasa yang diinginkan, termasuk dari bahasa Inggris ke dalam bahasa Indonesia. Namun demikian, seringkali pembelajar menemukan kesalahan dan kejanggalan dalam penerjemahan teks yang dimasukkan. Tujuan penelitian ini adalah untuk menganalisis keefektifan Google Translator sebagai media pembelajaran bahasa dilihat dari hasil terjemahannya. Dalam dunia penerjemahan, ada dua bentuk kesepadanan yang menjadi acuan, yaitu kesepadanan formal dan kesepadanan dinamis. Penelitian ini adalah penelitian deskriptif kualitatif untuk satu kasus. Data objektif yang dianalisis adalah naskah teks hasil terjemahan pada berita di media online dari kantor berita asing yang dijadikan teks sumber. Teknik pengambilan sampel berita dilakukan secara acak. Dari hasil penelitian, ditemukan fakta bahwa bentuk kesepadanan formal hampir dapat dicapai oleh teks terjemahan Google Translator. Namun, berdasarkan parameter dan skala keberterimaan yang peneliti gunakan, dapat disimpulkan bahwa teks 
hasil terjemahan Google Translation tidak tergolong dalam teks terjemahan dengan keberterimaan yang baik. Sementara itu, teks terjemahan dari jurnalis kompas.com sebagai pembanding masuk ke dalam kategori teks terjemahan dengan keberterimaan yang baik. Berdasarkan hasil analisis tersebut, Google Translation tergolong efektif sebagai media pembelajaran bahasa, meskipun dari sisi keberterimaannya, teks terjemahan Google Translation tergolong teks terjemahan yang tidak berterima.

Kata Kunci: google translation, media pembelajaran bahasa, keberterimaan terjemahan, terjemahan teks berita

\section{PENDAHULUAN}

Penerjemahan adalah cara mengalihkan pesan dari satu bahasa ke bahasa lain, dalam hal makna maupun bentuk bahasanya. Dengan menerjemahkan suatu bahasa, kita juga belajar bahasa, baik bahasa sumber maupun bahasa sasaran, selain bidang kajian yang diterjemahkan (Wuryantoro, 2015: 1).

Secara historis, penerjemahan dilakukan oleh seseorang yang memiliki kemampuan bilingual dan dilengkapi dengan pengetahuan khusus tentang topik yang akan diterjemahkan. Pada abad ke-20 pertengahan, teori tekstual dan analisis wacana membuka jalan bagi penerjemah modern yang memiliki keahlian transfer linguistik untuk menerapkan pendekatan whole text (teks/wacana secara keseluruhan) dalam melakukan kegiatan penerjemahan. $\mathrm{Hal}$ ini ditambah lagi dengan revolusi digital yang dimulai pada tahun 90-an dan menyebabkan peningkatan permintaan penerjemahan. Pada akhirnya, muncul translation tools, yang pada prinsipnya adalah terjemahan berbasis Teknologi Informasi dan Komunikasi (TIK) (Garcia, 2009: 1).

Sesuai dengan fenomena aktual dan historis yang ada dalam dunia terjemahan, dapat kita lihat bahwa dunia penerjemahan kini semakin dibuat mudah dengan perkembangan TIK. Mahasiswa atau peserta didik yang membutuhkan teori atau materi belajar dari sumber asing dapat dengan mudah memperoleh terjemahannya melalui fasilitas mesin penerjemah, seperti Google Translator, Bing Translator, Yandex Translator, Babelxl, atau Dictionary.com. Namun demikian, beberapa penelitian menyebutkan bahwa hasil terjemahan yang terlahir dari perangkat TIK tersebut masih belum dapat diandalkan.

Munculnya teknologi Translation Memory membawa perubahan pada peran penerjemah. Penerjemah tidak lagi terfokus pada penerjemahan teks, tetapi hanya melakukan perubahan pada bagian-bagian teks (segmen teks). Penerjemah hanya akan memeriksa dan/atau mengedit, tidak menerjemahkan (Hennessy dalam Garcia, 2008: 3).

Mesin penerjemah Google Translator, berbasis pada statistically based machine translation yang mampu menerjemahkan dokumen, teks atau halaman web ke dalam bahasa lain. Fasilitas ini merupakan hasil pengembangan dari penelitian yang dilakukan oleh Franz Joseph Och, yang pada tahun 2003 memenangkan kontes kecepatan mesin penerjemah (Santoso, 2010: 6).

Wuryantoro menemukan beberapa bukti bahwa hasil terjemahan dengan menggunakan mesin penerjemah mempunyai banyak kesalahan, baik di tingkat kata, frasa, ataupun kalimat yang sangat dipengaruhi oleh konteks yang ada. Namun, mesin penerjemah ini sangat membantu meringankan tugas dalam menerjemahkan meskipun banyak kekurangannya (Wuryantoro, 2015: 1).

Dari hasil analisis yang dilakukan Santoso terhadap kesalahan penerjemahan Google Translator, dari bahasa Indonesia ke dalam bahasa Jerman, ditemukan bahwa kesalahan terbanyak terjadi pada tataran morfologi, kemudian disusul kesalahan pada tataran semantik, sintaksis, kemudian ortografi. Hasil 
terjemahan dari sebuah mesin penerjemah semacam ini masih memiliki banyak kekurangan dan tidak menghasilkan terjemahan yang akurat, sehingga hasil terjemahan tersebut lebih layak disebut sebagai pre-translation yang masih perlu disempurnakan oleh penggunanya. Meskipun demikian, hasil terjemahan dari Google Translator, ini dapat dimanfaatkan untuk memahami sebuah teks secara global. Bagi para pengajar di perguruan tinggi, mesin penerjemah ini cukup membantu untuk mengalihbahasakan abstrak ke dalam bahasa lain, terutama bahasa Inggris (Santoso, 2010: 10-11).

Dalam dunia pembelajaran, pemanfaatan Google Translator, memberikan dampak terhadap hasil belajar. Hasil penelitian menunjukkan bahwa media pembelajaran Power Point berbasis Google Translator, berpengaruh positif dan signifikan terhadap peningkatan kemampuan pemahaman kosakata bahasa Inggris. Dari 24 siswa yang ada pada kelas kontrol (kelas A), 22 siswa atau sekitar $83 \%$ berada pada interpretasi peningkatan pemahaman kosakata yang rendah dan 2 siswa atau sekitar $17 \%$ berada pada interpretasi peningkatan pemahaman kosakata yang sedang. Sementara itu, dari 26 siswa yang ada pada kelas eksperimen (kelas B), 23 siswa atau sekitar 89\% berada pada interpretasi peningkatan pemahaman kosakata yang sedang dan 3 siswa atau sekitar $11 \%$ berada pada interpretasi peningkatan kosakata yang tinggi dan tidak ada siswa yang berada pada interpretasi peningkatan pemahaman kosakata yang rendah (Sofyanti, 2014: 9).

Fenomena manfaat dan perubahan signifikan terhadap siswa yang menggunakan Google Translator dalam pembelajaran bahasa sangat bertolak belakang dengan hasil penelitian yang menyebutkan bahwa Google Translator hanya dapat dimanfaatkan sebagai Pre-Translation (Santoso, 2010: 10-11).

Salah satu manfaat Google yang dapat dipakai oleh masyarakat umum adalah kemampuan Google menerjemahkan teks berita secara keseluruhan. Dengan demikian, berita dari belahan dunia manapun dapat dibaca dan dimengerti oleh masyarakat di seluruh dunia. Dalam pembelajaran di sekolah-sekolah, khususnya jenjang pendidikan menengah, tidak jarang para guru bahasa Inggris juga memberikan tugas memahami teks berita kepada siswasiswanya. Tugas pemahaman terhadap teks berita sangat mudah dikerjakan dengan hadirnya Google Translator.

Pemahaman terhadap teks berita asing menjadi penting ketika kebutuhan akan informasi semakin meningkat. Sejalan dengan itu, kebenaran informasi yang didapatkan seharusnya menjadi pegangan yang kuat bagi para penulis maupun pembacanya. Ketepatan atau keakuratan makna dalam menerjemahkan fakta yang disampaikan pada teks sumber berita internasional menjadi sangat penting karena kekuatan berita ada pada kesesuaian faktanya. Akan sangat membahayakan jika sebuah teks berita dipahami berbeda oleh peserta didik atau pembacanya hanya karena kesalahan yang dilakukan oleh mesin penerjemahan.

Oleh karena itu, tujuan penelitian ini adalah untuk menganalisis keefektifan Google Translator jika dijadikan sebagai media pembelajaran bahasa, jika dilihat dari hasil terjemahannya. Adapun hasil terjemahan yang saya gunakan untuk bahan analisis adalah teks berita asing. Teks berita diambil sebagai teks sumber karena teks berita merupakan jenis teks yang umum dibaca masyarakat, bahkan bisa menjadi salah satu materi dalam pembelajaran kosa kata bahasa Inggris.

Sebagai pembanding, penelitian ini juga akan menganalisis hasil terjemahan yang dilakukan oleh penerjemah berita profesional yang bekerja di kantor berita dengan hasil terjemahan Google Translator agar terlihat jelas perbedaan dari sisi keberterimaan hasil terjemahannya dan kesepadanan yang digunakan. Larson (1984) menyatakan bahwa penerjemahan merupakan pengalihan makna dari bahasa sumber ke dalam bahasa sasaran. Pengalihan ini dilakukan dari bentuk bahasa pertama ke dalam bentuk bahasa kedua melalui struktur semantik. Pernyataan tersebut menunjukkan bahwa pengalihan makna merupakan unsur yang sangat penting dalam menerjemahkan dengan 
memperhatikan struktur semantiknya. Kegiatan ini membutuhkan kemampuan tersendiri bagi seorang penerjemah karena bila penerjemah kurang mampu dalam melakukan kegiatan mengalihkan makna yang didasarkan pada pertimbanganpertimbangan tertentu sebelum mengambil keputusan maka hasil yang dicapainya kurang maksimal ataupun akan sia-sia.

Nida dan Taber (1969) berpendapat bahwa penerjemahan merupakan kegiatan reproduksi dalam bahasa sasaran dengan padanan yang sealamiah mungkin dari pesan bahasa sumber, pertama dalam segi makna dan kedua dalam segi bentuk. Menurut Nida dan Taber, dalam mereproduksi pesan, aspek makna merupakan prioritas utama dalam menerjemahkan tanpa mengabaikan pentingnya bentuk bahasa.

Dalam kegiatan penerjemahan, ada dua hal yang menjadi sorotan utama bagi seorang penerjemah, yaitu: (1) teks bahasa sumber yang akan diterjemahkan yang dipengaruhi oleh sistem bahasa dan budaya yang dimilikinya; dan (2) teks yang dihasilkan dari proses pengalihan, teks bahasa sasaran, yang pastinya mempunyai sistem bahasa dan budaya yang berbeda dengan bahasa sumber. Dengan demikian, seorang penerjemah dalam menerjemahkan bukan hanya harus memahami apa makna yang tersurat dalam suatu teks, namun juga dapat menyepadankan makna teks yang sesuai dengan nilai budaya yang ada dalam bahasa sumber.

Menurut Rossi dan Breidle dalam (Sanjaya, 2010:204), media pembelajaran adalah seluruh alat dan bahan yang dapat dipakai untuk tujuan pendidikan, seperti radio, televisi, buku, koran, majalah, dan sebagainya. Menurut Rossi, alat-alat semacam radio dan televisi kalau digunakan dan diprogram untuk pendidikan merupakan media pembelajaran. Menurut Kustandi (2011:9), media pembelajaran adalah alat yang dapat membantu proses belajarmengajar dan berfungsi untuk memperjelas makna pesan yang disampaikan sehingga dapat mencapai tujuan pembelajaran dengan lebih baik dan sempurna.

TIK dapat dan harus menjadi elemen kunci dalam kurikulum, karena pembelajaran dengan TIK adalah cara pembelajaran yang konsisten dan konstruktif untuk pengembangan keterampilan profesional (Chouc, 2010: 1). TIK menjadi salah satu media pembelajaran yang memiliki peran penting dalam proses transfer ilmu. Guru tidak lagi menjadi satu-satunya sumber ilmu. Peserta didik dapat dengan mudah mendapatkan materi pelajaran yang ingin diketahuinya hanya dengan satu klik, yaitu dengan perangkat TIK.

Demikian juga halnya dengan materi yang menggunakan bahasa Inggris. Para siswa tidak perlu kesulitan lagi untuk mengetahui maksud teori yang ada pada materi yang menggunakan bahasa Inggris tersebut. Hanya dengan menyalin materi di web Google Translator, siswa sudah dapat mengetahui maknanya. Hal ini seperti yang diungkapkan oleh Wuryantoro, yaitu bahwa mesin penerjemah sangat membantu meringankan tugas dalam menerjemahkan meskipun banyak kekurangannya (Wuryantoro, 2015:1).

Dalam pengajaran bahasa asing, para pakar telah membagi status bahasa Inggris menjadi 2 kategori, yaitu Bahasa Inggris sebagai bahasa asing dan Bahasa Inggris sebagai bahasa ke dua. Hal ini terkait dengan lingkungan belajar yang dapat menentukan proses belajar-mengajar peserta didik. Guru perlu mengetahui pada lingkungan apa proses belajar-mengajar itu terjadi, apakah mengajarkan bahasa sebagai bahasa kedua atau sebagai bahasa asing karena faktor tersebut sangat menentukan materi ataupun metode yang digunakan dalam proses belajar (Tim Pengembang Ilmu Pendidikan UPI, 2007).

Pembelajaran di Indonesia memosisikan bahasa Inggris sebagai bahasa asing karena bahasa Inggris belum menjadi bahasa percakapan sehari-hari peserta didik. Terkait dengan pemanfaatan TIK dalam pembelajaran Bahasa Inggris, bagi guru bahasa, internet merupakan media yang sangat sempurna. Guru dan peserta didik dapat memanfaatkanya untuk menjaring materi, baik berupa teks, video maupun audio (Dudeney, 2000).

Berikut adalah salah satu contoh web yang bisa dimanfaatkan sebagai media pembelajaran bahasa. 


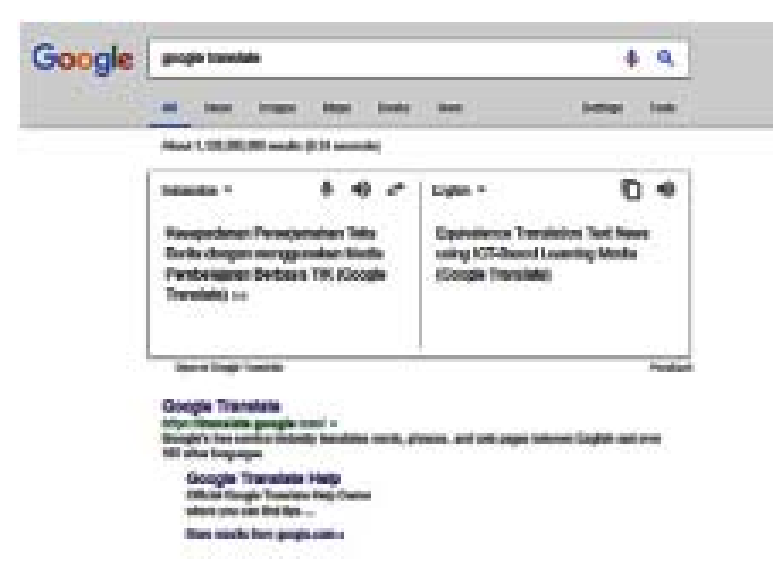

Gambar 1. Web Google Translation

Google Translator merupakan salah satu penerjemah bahasa yang dipersembahkan oleh Google. Google Translator menerjemahkan bahasa menggunakan pendekatan yang disebut dengan penerjemahan berdasarkan statistik. Sistem penerjemah dalam Google Translator ini memerlukan koneksi teks paralel dalam dua bahasa, yang terdiri lebih dari satu juta kata dan dua koleksi teks lainnya untuk masingmasing bahasa yang terdiri lebih dari satu miliar kata. Google Translator dapat menerjemahkan bahasa Inggris ke dalam bahasa Indonesia, demikian juga sebaliknya.

Kamus dan tabel frasa merupakan basis yang digunakan sistem mesin terjemahan seperti Google Translator dalam menerjemahkan, baik kata, frasa, maupun kalimat (Mikolov, Quoc \& Ilya, 2013:1). Strategi penerjemahan yang umumnya digunakan oleh Google Translator adalah harfiah/literal, serapan/transference, peminjaman kata asing/loan word, dan campuran (gabungan dari dua atau tiga strategi penerjemahan).

Penelitian untuk pengembangan mesin terjemahan yang lebih akurat banyak dilakukan, salah satunya adalah penelitian yang berjudul "Exploiting Similarities among Languages for Machine Translation" (Mikolov, Quoc \& Sutskever, 2013). Dalam penelitian ini dikembangkan potensi mesin terjemahan dalam menerjemahkan kata-kata yang secara tata bahasa jauh berbeda namun menghasilkan terjemahan yang mendekati kesepadanan dengan menggunakan sejumlah data monolingual dan kamus kecil sederhana seperti antara Bahasa Inggris dan Czech, atau Inggris dan Vietnam.

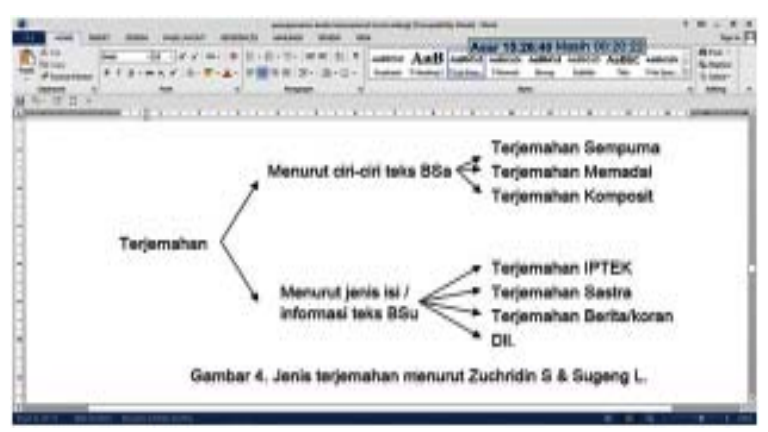

Gambar 2. Diagram Jenis Jenis Terjemahan

Pada diagram jenis terjemahan menurut Zuchridin dan Sugeng (2003), terjemahan berita menjadi salah satu jenis terjemahan yang dikategorikan berdasarkan jenis atau isi dari informasi teks bahasa sumber. Tidak dapat dipungkiri bahwa memang jenis terjemahan berita dipengaruhi pada pertimbangan bisnis sehingga kerapkali isi berita hasil terjemahan berbeda sudut pandang penulisannya dengan teks aslinya.

Menurut Bani (2006), meskipun globalisasi media kini menjadi hal yang menarik diperbincangkan, namun peran penerjemahan media ternyata tidak lepas dari perhatian. Hal ini dibuktikan dengan mudahnya berita-berita internasional masuk ke berbagai negara yang berbeda. Bahkan, meskipun tidak melampirkan fakta data pada artikelnya, menurut Bani, penerjemahan pers mendapatkan banyak pembaca dibandingkan dengan penerjemahan kesusasteraan. Selain itu, penerjemahan berita juga memiliki peran terhadap perkembangan pendapat masyarakat internasional atas kejadiankejadian yang ada di seluruh dunia.

Bani mengkarakterisasikan penerjemahan berita sebagai penerjemahan yang menuntut kecepatan penerjemahnya dalam menyelesaikan tugas terjemahan. Dua kecepatan yang dituntut pada penerjemahan berita adalah: kecepatan dalam menerjemahkan dan kecepatan dalam mengembangkan penerjemahan.

Menurut Gambier (2006), ada beberapa tahapan proses antara mendapatkan fakta di lapangan sampai dengan menjadi produk akhir berita, dan dicetak untuk para pembaca. 
Penerjemahan menjadi bagian dari tahapantahapan itu. Selain tahapan penerjemahan, juga dilakukan tahap editing oleh editor sehingga menjadi proses transediting, yaitu mengubah bahasa dan struktur pesan Bahasa Sumber (BSu) dengan menggunakan strategi reorganisasi, penghapusan (deletion), penambahan (addition), dan penggantian (substitution).

Reorganisasi adalah merubah struktur Teks Sumber (TSu) dengan cara (1) memperhatikan kembali informasi yang ada pada masing-masing paragraf dalam sebuah berita; dan (2) memindahkan atau mengubah beberapa fakta yang ada dalam berita ke bagian-bagian atau paragraf lain dalam susunan badan berita. Reorganisasi dapat dilakukan pada bagian per bagian berita karena adanya perbedaan bahasa, tradisi retorika yang berlaku di salah satu negara, dan untuk memenuhi target jumlah pembaca.

Berkaitan dengan penghapusan, persentase jumlah bagian-bagian yang dihilangkan pada penerjemahan berita tergantung pada (1) jumlah fakta yang ada pada berita, (2) tingkatan ketepatan, dan (3) pengulangan (unsur segmental yang dilebihlebihkan dalam ujaran) pada teks sumber. Menurut Gambier, rata-rata jumlah penghilangan atau penghapusan bagian teks sumber sebesar 60\%-25\% tergantung pada teks sumbernya.

Pada penerjemahan berita, biasanya penerjemah membutuhkan kalimat-kalimat penjelas, membuat informasi tambahan yang lebih eksplisit, membuat asumsi, dan lainlain. Menurut Gambier, hal ini sama dengan transfer bahasa dalam penerjemahan audiovisual, meskipun kebanyakan orang beranggapan bahwa penerjemahan audiovisual lebih cenderung melakukan strategi penghilangan atau penghapusan.

Melalui penggantian, penerjemah akan membuat hal-hal yang kecil menjadi lebih detail. Penerjemah terkadang harus mengubah fokus teks, mengganti penyebutan nama narasumber (seperti menyebutkan jabatan seorang narasumber atau posisinya di pemerintahan tempat narasumber bertugas, meskipun pada teks aslinya tidak dicantumkan), dan diakhiri dengan membuat rangkuman atau kesimpulan.

Hal lain yang harus diperhatikan dalam penerjemahan adalah aspek keberterimaan teks terjemahan. Aspek ini harus diperhatikan oleh penerjemah karena perbedaan antara satu bahasa dengan bahasa lainnya tidak hanya menyangkut perbedaan struktur gramatikal saja, namun juga menyangkut kaidah, kebiasaan, ataupun norma budaya. Menurut Nida dan Taber dalam Hoed (2006), penerjemahan yang baik adalah penerjemahan yang berorientasi pada keberterimaan dalam bahasa pembacanya.

Nababan (2012) menyatakan bahwa tingkat keberterimaan teks terjemahan mengacu pada kesesuaian kaidah penulisan teks terjemahan pada bahasa sasaran. Dapat saja terjemahan yang dihasilkan pada teks berita akurat atau sesuai dengan teks sumber, namun belum tentu terjemahan tersebut berterima dengan kaidah bahasa sasaran, yakni bahasa Indonesia. Dengan demikian, penting untuk mengetahui tingkat keberterimaan terjemahan naskah berita internasional.

Berikut ini adalah paramater dan skala yang peneliti gunakan untuk mengetahui tingkat keberterimaan teks terjemahan berita internasional.

\begin{tabular}{lcl}
\hline Kategori & Skor & Parameter \\
\hline Berterima & 3 & $\begin{array}{l}\text { Terjemahan alami, istilah- } \\
\text { istilah yang ada pada teks } \\
\text { sasaran biasa digunakan } \\
\text { pada Bahasa Sasaran (Bsa) } \\
\text { dan akrab bagi peneliti. }\end{array}$ \\
\hline $\begin{array}{ll}\text { Kurang } \\
\text { Berterima }\end{array}$ & 2 & $\begin{array}{l}\text { Terjemahan sudah terasa } \\
\text { alami, namun terjadi } \\
\text { kesalahan } \\
\text { dalam penerjemahan } \\
\text { istilah-istilah yang ada } \\
\text { pada teks sumber }\end{array}$ \\
\hline $\begin{array}{l}\text { Tidak } \\
\text { Berterima }\end{array}$ & 1 & $\begin{array}{l}\text { Terjemahan tidak alami atau } \\
\text { terlihat seperti karya } \\
\text { terjemahan, istilah-istilah } \\
\text { yang digunakan tidak biasa } \\
\text { dan tidak akrab bagi peneliti. }\end{array}$ \\
\hline
\end{tabular}




\section{METODA}

Pendekatan yang digunakan pada penelitian ini adalah pendekatan kualitatif. Cresswell dalam Raco (2010) mendefinisikan pendekatan kualitatif sebagai suatu pendekatan atau penelusuran untuk mengeksplorasi dan memahami suatu gejala sentral. Untuk memahami gejala sentral tersebut, peneliti harus menggali informasi berupa kata atau teks yang kemudian dianalisis. Hasil analisis dapat berupa penggambaran atau deskripsi dan dapat pula dalam bentuk tema-tema. Dari data tersebut, peneliti membuat interpretasi untuk mendapatkan arti yang mendalam. Dalam hal ini, peneliti akan menghimpun data atau informasi, teks berita internasional yang telah ditayangkan, dan sumber beritanya.

Dalam bukunya Research Design: Qualitative and Quantitative Approaches (1994), Cresswell menyebutkan bahwa tahapan atau prosedur dalam pendekatan kualitatif meliputi langkah-langkah: (1) the assumptions of qualitative designs; (2) the type of design; (3) the researcher's role; (4) the data dollection procedures; (5) data recording procedures; (6) data analysis procedures; (7) verification steps; dan (8) the qualitative narrative.

Melalui pendekatan ini, diharapkan akan ada analisis yang menghasilkan pemahaman mendalam terhadap hasil terjemahan Google Translation, dilihat dari unsur keberterimaan dan kesepadanannya. Oleh karena itu, melalui pendekatan ini peneliti mencoba mengetahui bentuk kesepadanan teks terjemahannya, lalu menganalisis strategi yang digunakan penerjemah untuk mencapai kesepadanan yang terdekat dan terwajar, serta untuk mengetahui secara mendalam kualitas terjemahan yang ditentukan oleh 3 hal, yaitu: ketepatan, keberterimaan, dan keterbacaan teks terjemahan.

Metode penelitian yang digunakan sesuai dengan jenis penelitian kualitatif adalah metode analisis isi. Krippendorf (2004) mendefinisikan analisis isi sebagai teknik penelitian untuk membuat kesimpulan dari teks yang valid dan replicable dengan konteksnya. Adapun data atau teks yang dianalisis oleh penulis adalah yang berupa teks-teks sumber dari kantor berita internasional dan teks-teks sasaran dari terjemahan berita-berita internasional di media online "Kompas.com".

Peneliti menggunakan pendekatan induktif. Neuman dalam Hamad (2004) menjabarkan pendekatan induktif sebagai pendekatan penelitian untuk melakukan pengamatan terhadap realitas empiris dengan memanfaatkan kerangka teori (theoritical framework) sebagai acuan untuk memahami suatu realitas sosial. Teori-teori dan konsep yang berada dalam kerangka teori dipakai bukan untuk diuji tingkat realitasnya namun untuk lebih memahami realitas empiris di lapangan.

Peneliti mencari 5 teks sumber dan 5 teks sasaran yang berisikan berita-berita internasional di media dalam jaringan Kompas.com. Kemudian peneliti menganalisis bentuk kesepadanan antara teks sumber dan teks sasaran. Setelah itu, peneliti mengidentifikasi strategi penerjemahan teks-teks berita internasional di media dalam jaringan "Kompas.com" sebagai Teks Sasaran (Tsa) dan naskah berita dari beberapa kantor berita internasional seperti Reuters, AFP, dan Gulf News sebagai Teks Sumber (Tsu). Analisis teks dilakukan pada masing-masing kalimat yang ada pada teks terjemahan, sehingga didapatkan strategi yang paling sering digunakan oleh penerjemah. Tahap akhir adalah dengan menelaah kembali dampak strategi yang digunakan terhadap keakuratan, keberterimaan, dan keterbacaan teks sasaran. Teks sumber juga akan dicoba diterjemahkan dengan mesin penerjemahan Google Translator dan dilakukan analisis yang sama dengan hasil terjemahan dari kantor berita.

\section{HASIL DAN PEMBAHASAN}

\section{Analisis Terjemahan Kantor Berita}

Berikut ini adalah hasil analisis yang peneliti lakukan pada terjemahan di kompas.com yang sumber beritanya diambil dari beberapa kantor berita asing seperti AFP, Gulfnews, Reuters, dan lain-lain. Terdapat 
107 kalimat terjemahan yang memenuhi parameter penilaian sebagai terjemahan yang berterima, yaitu terjemahan alami, istilahistilah yang ada pada teks sasaran biasa digunakan pada TSa dan akrab bagi peneliti. Berikut ini adalah contoh terjemahan berterima.

Tabel 2: Terjemahan Kalimat Lead Berita dari The Telegraph

Tsu Last tweet before conclave: May Our Father hear and answer with love and mercy all prayers and sacrifices offered for fruitful outcome. God bless!", South African cardinal Wilfrid Napier told his thousands of followers.

Tsa "Tweet terakhir sebelum konklaf: Semoga Bapa mendengar dan menjawab dengan cinta semua doa dan pengorbanan akan berbuah. Tuhan memberkati!" kata Kardinal Afrika Selatan, Wilfrid Napier, kepada ribuan follower-nya.

Istilah-istilah yang ada pada situs jejaring sosial di atas adalah istilah yang sudah dikenal masyarakat, sehingga keputusan penerjemah untuk tidak menerjemahkannya menjadi "kicauan" dan "pengikut" sudah sangat tepat, karena jika diterjemahkan justru akan menjadi terasa tidak alami.

Tabel 3 Terjemahan Judul Berita

\begin{tabular}{cl}
\hline Tsu & $\begin{array}{l}\text { Nepali TV host earns Guinness } \\
\text { record for longest talk show }\end{array}$ \\
\hline Tsa & $\begin{array}{l}\text { Pria Nepal Pecahkan Rekor } \\
\text { "Talk Show" Terlama }\end{array}$ \\
\hline
\end{tabular}

Istilah talkshow juga sudah sangat dikenal masyarakat sehingga judul berita ini sudah berterima di masyarakat Indonesia meskipun tidak diterjemahkan menjadi "Acara BincangBincang".

Terdapat beberapa terjemahan yang dikategorikan sebagai terjemahan kurang berterima. Menurut peneliti, dari 129 kalimat yang diterjemahkan, ada 20 kalimat terjemahan yang kurang berterima. Berikut adalah contoh terjemahan yang kurang berterima.
Tabel 4 Terjemahan Judul Berita

\begin{tabular}{cl}
\hline Tsu & $\begin{array}{l}\text { Hamas arrests 'collaborators' after } \\
\text { amnesty ends }\end{array}$ \\
\hline Tsa & $\begin{array}{l}\text { Hamas Mulai Tangkapi Kolaborator } \\
\text { Israel }\end{array}$ \\
\hline
\end{tabular}

Dalam penulisan judul berita, penerjemah sering menggunakan kata dasar tanpa diberikan afiksasi, seperti contoh di atas. Berikut ini adalah contoh lainnya.

Tabel 5 Terjemahan Badan Berita

\begin{tabular}{ll}
\hline & "This incident shows what kind of \\
brutes do we have in society. & Society is also responsible for this. \\
It has become full of perverts," said \\
Ranjana Kumari of the Delhi-based \\
Centre for Social Research.
\end{tabular}

Penulisan kata "cabul" untuk menggantikan kata perverts terasa tidak berterima pada budaya bahasa sasaran. Apalagi untuk media kompas yang memiliki target pembaca kelas menengah ke atas. Akan lebih baik jika ditulis menjadi "semakin banyak orang yang berperilaku menyimpang".

Untuk hasil terjemahan yang tidak berterima, didapatkan hasil analisis bahwa tidak ada terjemahan yang memenuhi parameter penilaian sebagai terjemahan yang tidak berterima karena penggunaan metode free translation dalam penerjemahannya sehingga terjemahan berita tersebut sangat terasa alami oleh peneliti.

\section{Analisis Terjemahan melalui Google Translation}

Berikut ini adalah contoh hasil analisis dan perbandingan hasil terjemahan oleh penerjemah di Kompas.com dan penerjemahan berita melalui Google 
Translation. Dari 8 berita yang dianalisis, diambil beberapa kalimat secara acak yang memenuhi bagian-bagian dalam struktur berita, seperti: judul, lead berita, body berita, kalimat penutup berita, dan kalimat langsung petikan hasil wawancara.

Hampir semua kalimat yang diterjemahkan melalui mesin penerjemahan berbasis TIK yaitu Google Translator tidak memiliki unsur keberterimaan seperti terjemahan dari kantor berita "Kompas.com". Hal ini semakin menguatkan penelitian-penelitian sebelumnya yang mengatakan bahwa mesin penerjemah semacam ini masih memiliki banyak kekurangan dan tidak menghasilkan terjemahan yang akurat sehingga hasil terjemahan tersebut lebih layak disebut sebagai pre-translation yang masih perlu disempurnakan oleh penggunanya. Meskipun demikian, hasil terjemahan dari Google Translator ini dapat dimanfaatkan untuk memahami sebuah teks secara global.

Adapun pemanfaatannya untuk pembelajaran, hanya disarankan pada kalimat-kalimat singkat atau kata. Beberapa contoh hasil terjemahan yang tidak berterima antara lain:

Tabel 6 Terjemahan Lead Berita

\section{Teks Sumber}

Insurgents fired mortar rounds at one of President Bashar al-Assad's palaces in the Syrian capital on Tuesday, as the death toll mounted from a devastating missile strike on second city Aleppo.

\section{Terjemahan Google}

Gerilyawan menembakkan mortir di salah satu istana Presiden Bashar al-Assad di ibukota Suriah pada hari Selasa, sebagai korban tewas dipasang dari serangan rudal yang menghancurkan kota kedua Aleppo.

\section{Terjemahan Kompas.com}

Pemberontak Suriah menembakkan sejumlah mortir ke salah satu istana presiden Bashar ALAshad

Terjemahan di atas menggambarkan bahwa terjadi kesalahan morfologi dalam terjemahan Google Translator. Kalimat "sebagai korban tewas dipasang dari serangan.............." tidak memiliki makna yang jelas karena susunan gramatikal yang rusak. Konteks kalimat yang ada pada akhir kalimat tidak dapat terangkai dengan baik. Sedangkan terjemahan Kompas.com dianalisis sebagai terjemahan dengan metode free translation yaitu penerjemahan yang tidak terikat pada struktur dan ketentuan tertentu. Metode ini mengedepankan isi dibanding bentuknya, dan sering digunakan pada penerjemahan berita.

Berikut ini adalah contoh terjemahan pada bagian judul berita.

Tabel 7 Terjemahan Judul Berita

Teks Sumber

Hamas offers clemency for 'collaborators'

\section{Terjemahan Google}

Hamas menawarkan grasi untuk 'kolaborator'

\section{Terjemahan Kompas.com}

Hamas imbau Kolaborator Israel Bertobat

Pada kalimat-kalimat pendek seperti ini, terjemahan Google Translator hampir mendekati kesepadanan formal yaitu kesepadanan yang diarahkan untuk menangkap bentuk dan isi dari pesan asli. Bentuk pesan dan isi yang ada pada Google Translator tidak lebih dan tidak kurang. Sedangkan pada terjemahan "Kompas.com" masih diberikan kalimat yang mengundang pembaca untuk membacanya sehingga susunan kata pun diubah dengan tujuan meraih isi pesan yang serupa dengan kalimat yang lebih menarik bagi pembaca indonesia.

Tabel 8 Terjemahan Lead Berita

\section{Teks Sumber}

The Hamas yesterday launched a month-long campaign in Gaza urging alleged Palestinian "collaborators" with Israel to turn themselves in return for leniency.

\section{Terjemahan Google}

The Hamas kemarin meluncurkan kampanye selama sebulan di Gaza mendesak dugaan 
Palestina "kolaborator" dengan Israel untuk menyerahkan diri dengan imbalan keringanan hukuman.

\section{Terjemahan Kompas.com}

Penguasa Jalur Gaza, Hamas, Selasa (12/3/2013) memberikan waktu selama satu bulan untuk para kolaborator israel "menyerahkan diri". Hamas menjanjikan keringanan bagi mereka yang menyerahkan diri.

Namun demikian, kesepadanan formal tidak dapat dipertahankan oleh mesin penerjemahan Google Translator untuk menerjemahkan kalimat-kalimat panjang. Kata "the" yang tidak masuk ke dalam program mesin penerjemahan masih muncul dan membuat hasil terjemahan Google Translator terasa janggal. Pada kalimat-kalimat seperti ini Google Translator belum dapat membuat kesepadanan yang lebih dinamis sehingga keterbacaan makna dan pesan dapat terlihat baik.

Contoh lainnya adalah pada kalimat yang merupakan bagian judul dari sebuah berita.

Tabel 9 Terjemahan Judul Berita

\section{Teks Sumber}

Russian soldier missing in Afghanistan for 33 years is FOUND living as nomadic sheikh in remote Afghan province.

\section{Terjemahan Google}

Tentara Rusia yang hilang di Afghanistan selama 33 tahun adalah DITEMUKAN hidup sebagai syekh nomaden di provinsi Afghanistan terpencil.

\section{Terjemahan Kompas.com}

Hilang 33 tahun, Tentara Rusia ditemukan hidup Nomaden.

Secara sekilas, hasil terjemahan Google Translator dapat ditangkap dengan baik, hanya saja terjadi kesalahan susunan kalimat yang masih sering terjadi. Kesepadanan formal menjadi kelebihan yang dihasilkan terjemahan Google Translator. Sedangkan terjemahan Kompas.com mencari kesepadanan yang lebih dinamis, bahkan cenderung memilih pesan tertentu saja, dan mengabaikan pesan-pesan lainnya, dengan menggunakan strategi deletion yang menjadi salah satu strategi dalam metode penerjemahan teks berita.

Teks Sumber

Are cardinals electing the last pope? If you

believe Nostradamus...

\section{Terjemahan Google}

adalah kardinal pemilihan paus terakhir?

Jika Anda percaya Nostradamus

\section{Terjemahan Kompas.com}

Apakah Paus Baru adalah Paus Terakhir?

Contoh di atas menunjukkan kelemahan Google Translator dalam menyajikan makna pesan yang utuh. Perbaikan dalam morfologi hasil terjemahan merupakan salah satu bagian yang harus diutamakan. Berikut ini adalah beberapa contoh kesalahan-kesalahan morfologi yang terjadi pada beberapa kalimat berita.

Tabel 10 Terjemahan Kalimat Penutup Berita

Teks Sumber

Perhaps the end isn't so near.

Terjemahan Google

Mungkin akhirnya tidak begitu dekat.

Terjemahan Kompas.com

Dengan demikian, jika anda percaya legenda ini, maka akhir zaman tampaknya masih cukup jauh.

Tabel 11 Terjemahan Judul Berita

Teks Sumber

Hugo Chávez: Nine Unlikely Facts about Venezuela's Unusual Late Leader

Terjemahan Google

Hugo Chavez: Sembilan Fakta Tidak mungkin tentang Leader Akhir Unusual Venezuela

Terjemahan Kompas.com

Sembilan Fakta Unik Hugo Chavez 
Tabel 12 Terjemahan Badan Berita

\section{Teks Sumber}

Guinness World Records allowed a break of five minutes every hour. It was not clear how many people watched the show.

\section{Terjemahan Google}

Guinness World Records diperbolehkan istirahat lima menit setiap jam. Tidak jelas berapa banyak orang menonton pertunjukan.

\section{Terjemahan Kompas.com}

Dalam upaya pemecahan rekor ini, guinnes memberikan waktu istirahat selama lima menit setiap jam.

Tabel 13 Terjemahan Lead berita

\section{Teks Sumber}

Saudi Arabia's King Abdullah on Tuesday swore in the country's first female members of the shura council, an appointed body that advises on new laws, in a move that has riled conservative cleric in the islamic monarchy.

\section{Terjemahan Google \\ Raja Arab Saudi Abdullah pasa selassa melantik anggota perempuan pertama negara itu dari dewan syura, badan yang ditunjuk yang memberikan nasihat pada undang-undang baru, dalam sebuah langkah yang telah gusar ulama konservatif di monarki islam.}

\section{Terjemahan Kompas.com \\ Raja Arab saudi Abdullah bin andul aziz, selasa (19/2/2013), untuk pertama kalinya melantik perempuan sebagai anggota Dewan Syura Kerajaan. Dewan ini bertugas menjadi penasihat raja khususnya terkait penerbitan undang-undang baru.}

Jika dilihat secara keseluruhan, meskipun terjemahan Google Translator tidak dapat mengirim isi pesan secara sempurna, dengan sedikit perbaikan dan penghapusan, makna dan bentuk pesan dapat disampaikan dengan baik. Salah satu contoh yang dapat dilakukan adalah pada kalimat berikut ini. Tabel 14.

Tabel 14 Terjemahan Lead Berita

\section{Teks Sumber}

Russian soldier missing in Afghanistan for 33 years is FOUND living as nomadic sheikh in remote Afghan province

\section{Terjemahan Google}

Tentara Rusia yang hilang di Afghanistan selama 33 tahun adalah DITEMUKAN hidup sebagai syekh nomaden di provinsi Afghanistan terpencil

Terjemahan Kompas.com

Hilang 33 tahun, Tentara Rusia ditemukan hidup Nomaden.

Hasil perbaikan: "Tentara Rusia yang hilang di Afghanistan selama 33 tahun DITEMUKAN hidup sebagai syekh nomaden di provinsi terpencil Afghanistan".

\section{SIMPULAN DAN SARAN}

Berdasarkan hasil penelitian tentang keberterimaan terjemahan teks berita dengan menggunakan media pembelajaran berbasis TIK (Google Translator), dapat dikemukakan bahwa bentuk kesepadanan penerjemahan teks berita yang diterapkan di Google Translator cenderung pada bentuk kesepadanan formal. Namun demikian, isi pesan yang disampaikan seringkali tidak terbaca dengan baik. Perlu upaya perbaikan agar struktur kalimat terjemahan dapat sesuai dengan struktur bahasa Indonesia sehingga terjemahan dengan kategori keberterimaan yang memiliki hasil terjemahan alamiah dan mudah dipahami pembaca dapat terwujud. Terjemahan yang baik adalah terjemahan yang dapat mencapai kesepadanan dalam bentuk dan juga isi.

Kesalahan pada mesin penerjemahan Google Translator seringkali terjadi pada susunan kalimat yang panjang dan memiliki anak kalimat. Namun jika kalimat yang diterjemahkan adalah kalimat-kalimat singkat, Google Translator berhasil menerjemahkannya dengan bentuk dan isi yang sama.

Jika Google Translator dimanfaatkan oleh pembelajar dalam menerjemahkan teks berita dan teks-teks lainnya, para pembelajar harus menyadari bahwa mesin memiliki keterbatasan yang tidak dapat disamakan dengan penerjemah yang memahami bentuk morfologi, sintaksis dan semantik. Namun demikian, kehadiran mesin penerjemahan merupakan media belajar yang sangat membantu siswa dalam memahami kata demi kata dalam teks berita. 
Pengguna jasa Google Translator disarankan untuk memperhatikan kaidah penulisan bahasa Indonesia yang baik dan benar sehingga penulisan teks terjemahan dapat sesuai dengan kaidah Bahasa Indonesia.

Salah satu strategi yang dapat digunakan ketika menerjemahkan teks dengan menggunakan Google Translator adalah dengan cara menerjemahkan kalimat demi kalimat karena penggunaan kalimat yang panjang hanya membuat struktur terjemahan yang dihasilkan Google tidak memiliki keterbacaan yang baik.

Bagi pembelajar, Google Translator dapat dimanfaatkan, baik untuk pembelajaran pemahaman kosa kata maupun struktur kalimat, karena belajar dari kesalahan kebahasaan merupakan salah satu cara untuk dapat memahami kosa kata atau struktur menjadi lebih baik.

\section{PUSTAKA ACUAN}

\section{Buku}

Bani, Sara.2006. Translation in Global News. United Kingdom: University of Warwick.

Creswell, John W. 1994. Research Design; Qualitative and Quantitative Approaches. United Kingdom: SAGE Publications.

Dudeney, Gavin.2000. The Internet and the Language Classroom. United Kingdom: Cambridge University Press.

Gambier, Yves. 2006. Transformation in International News. UK: University of Warwick.

García, Ofelia. 2009. Bilingual Education in the 21st Century: A Global Perspective. Malden, MA and Oxford: Basil/Blackwell.

Hoed, Beny. 2006. Penerjemahan dan Kebudayaan. Jakarta: Pustaka Jaya.

Hamad, Ibnu. 2004. Konstruksi Realitas Politik dalam Media Massa. Jakarta: Granit.

Krippendorff, Klauss. 2004. Content Analysis: An Introduction to its Methodology. United Kingdom: Sage Publications.

Kustandi. 2012. Media Pembelajaran: Manual dan Digital. Bogor: Ghalia Indonesia.

Nida, A. Eugene, dan Charles Russel Taber. 1974.The Theory and the Practice of Translation. Leiden: E.J.Brill.

Raco J.R. , M.E.,M.Sc. 2010. Metode Penelitian Kualitatif; Jenis, Karakteristik dan Keunggulannya. Jakarta: Grasinda.

Sanjaya. 2010. Strategi Pembelajaran berorientasi
Standar Proses Pendidikan. Jakarta: Kencana Pranada Media.

Suryawinata, Zuchridin, Sugeng L., 2003. Translation Bahasan Teori dan Penuntun Praktis Menerjemah. Yogyakarta: Kanisius.

Tim Pengembang Ilmu Pendidikan UPI Bandung. 2007. Ilmu dan Aplikasi Pendidikan. Grasindo: Bandung.

\section{Jurnal/prosiding/disertasi/tesis/skripsi}

Garcia, Ignacio. 2009. Beyond Translation Memory: Computers and the Professional Translator. The Journal of Specialised Translation, Issue 12-July 2009. Hal. 201-202. Tersedia di: http://jostrans.org/issue12/ art_garcia.pdf diunduh Januari 2017.

García, Ofelia. 2008. Spanish as a Global Language. The International Multilingual Research Journal 2, Issue 1. Routledge: Taylor \& Francis.

Sofyanti, Yanti. 2012. Pengaruh Penggunaan Media Pembelajaran Power Point Berbasis Google Translation terhadap Pemakaian Kosakata Bahasa Inggris. Jurnal Wawasan IImiah AMIK Garut, Vol. 5, No.10. Hal 9-10. Tersedia di: http://jurnal.amikgarut.ac.id/ index.php/jwi/article/view/8/7 (diunduh pada Januari 2017)

Wuryantoro, Aris. 2015. Analisis Hasil Terjemahan dalam Pengajaran Penerjemahan. E-Journal IKIP PGRI Madiun. Hal 13-14. Tersedia di : file://C:/Users/Win\%207\%20Pro/Downloads/ 118-209-1-SM.pdf (diunduh Januari 2017).

\section{Lain-lain}

Goldberg, John dan Louis Markoczy. Complex Rhetoric and Simple Games. Cranfield University. Tersedia di: http: // www.Cranfield.ac.za/public/ cc/cc047/ papers/ complex/html/ complex.html, diakses 30 Agustus 2000.

Santoso, Iman. 20100 Analisis Kesalahan Kebahasaan Hasil Terjemahan Google Translation Teks Bahasa Indonesia ke dalam Bahasa Jerman. Hal 4-10. Tersedia di: http:// eprints.uny.ac.id/2865/ (diunduh pada Januari 2017).

Tomas Mikolov, Quoc V. Le, llya Sutskever. 2013. Exploiting Similarities among Languages for Machine Translation. Hal. 9 tersedia di: https:/ /static.googleusercontent.com/media/ research.google.com/en//pubs/archive/ 44931.pdf (diunduh Januari 2017). 